\title{
SYSTEMIC LUPUS ERYTHEMATOSUS. CRYOPRECIPITATION OF SERA
}

\author{
By CHARLES L. CHRISTIAN,* WENDELL B. HATFIELD, $\dagger$ AND P. HARVEY CHASE $\ddagger$
}

(From the Department of Medicine, Columbia University College of Physicians and Surgeons, and the Edward Daniels Faulkner Arthritis Clinic of the Presbyterian Hospital, New York, N. Y.)

(Submitted for publication December 28, 1962; accepted February 13, 1963)

Sera of normal human subjects, when refrigerated $\left(0\right.$ to $\left.4^{\circ} \mathrm{C}\right)$, form negligible quantities of precipitate. A variety of pathologic states have been associated with serum cryoprecipitation: myelomatosis, Waldenström's macroglobulinemia, lymphosarcoma, kala azar, bacterial endocarditis, rheumatoid arthritis, periarteritis, and systemic lupus erythematosus (SLE) (1). Lerner, Watson, and Barnum suggested the term "cryoglobulins" for cold-precipitable elements of sera and established quantitative criteria for their studies $(2,3)$. When serum cryoproteins have been characterized, the majority have been homogeneous in electrophoretic and sedimentation studies. Cryoproteins of myeloma sera usually consist of the respective paraproteins. The cryoproteins separating from sera with "rheumatoid factor"

* Investigator of the Health Research Council of the City of New York under contract I-178. John and Mary R. Markle Foundation Scholar in the Medical Sciences.

† Trainee under U. S. Public Health Service grant 2A-5040 from the National Institute of Arthritis and Metabolic Diseases, Bethesda, Md.

$\ddagger$ Fellow, The National Foundation, New York, N. Y.
(RF) properties have been inhomogeneous, consisting in part of the RF (4-6).

This report concerns studies of SLE sera that precipitated at 0 to $4^{\circ} \mathrm{C}$. In $12 \mathrm{SLE}$ sera, the following were observed: 1) the association of cryoprecipitation with active disease manifestations, 2) inhomogeneity of cryoprecipitates consisting in part of 7 and $19 \mathrm{~S} \gamma$-globulin, and 3) the requirement for cryoprecipitation of a heatlabile $\left(30\right.$ minutes at $56^{\circ} \mathrm{C}$ ) component that could be supplied by normal human sera and the identification of the heat-labile substance as a recently characterized component of serum complement.

\section{MATERIALS AND METHODS}

1. Blood samples obtained from patients in the Edward Daniels Faulkner Arthritis Clinic and the Presbyterian Hospital were allowed to clot in a $37^{\circ} \mathrm{C}$ water bath. Sera were separated from clotted blood by brief centrifugation at room temperature. The studies to be described were performed on fresh, unfrozen sera. See Table I for a summary of clinical and laboratory features of the 12 patients included in the present study.

2. Serum reagents for titration of complement components were prepared by previously reported methods

TABLE I

Summary of clinical and laboratory features of patients in the present study*

\begin{tabular}{|c|c|c|c|c|c|c|c|c|c|c|c|c|}
\hline \multirow[b]{2}{*}{ Patient } & \multicolumn{5}{|c|}{ Systemic manifestations } & \multirow{2}{*}{$\begin{array}{c}\text { Anemia, } \\
<10 \mathrm{~g} \\
\text { hemoglobin }\end{array}$} & \multirow{2}{*}{$\begin{array}{c}\text { Leukopenia, } \\
<5,000 \\
\text { leukocytes }\end{array}$} & \multirow[b]{2}{*}{$\begin{array}{l}\text { LE prep. } \\
\text { positive }\end{array}$} & \multirow{2}{*}{$\begin{array}{c}\text { Rheumatoid } \\
\text { factor } \\
\text { present }\end{array}$} & \multicolumn{3}{|c|}{ Status in December, 1962} \\
\hline & Arthritis & Serositis & $\underset{\text { lesions }}{\text { Skin }}$ & Nephritis & $\begin{array}{c}\text { Ray- } \\
\text { naud's }\end{array}$ & & & & & $\begin{array}{l}\text { Moderate } \\
\text { remission }\end{array}$ & $\begin{array}{l}\text { Active } \\
\text { SLE }\end{array}$ & Dead \\
\hline E.T. & $\mathbf{x}$ & $\mathbf{x}$ & $\mathbf{x}$ & $\mathbf{x}$ & $\mathbf{x}$ & $\mathbf{x}$ & $\mathbf{x}$ & $\mathbf{x}$ & & & & $\mathbf{x}$ \\
\hline M.H. & $\mathbf{x}$ & $\mathbf{x}$ & $\mathbf{x}$ & $\mathbf{x}$ & $\mathbf{x}$ & & $\mathbf{x}$ & $\mathbf{x}$ & $\mathbf{x}$ & & & $\mathbf{x}$ \\
\hline E.S. & $\mathbf{x}$ & & $\mathbf{x}$ & & & & & $\mathbf{x}$ & & $\mathbf{x}$ & & \\
\hline H.M. & $\mathbf{x}$ & & $\mathbf{x}$ & $\mathbf{x}$ & & $\mathbf{x}$ & & $\mathbf{x}$ & & ? & ? & ? \\
\hline R.J. & $\mathbf{x}$ & $\mathbf{x}$ & & $\mathbf{x}$ & & $\mathbf{x}$ & $\mathbf{x}$ & $\mathbf{x}$ & & ? & ? & ? \\
\hline J.C. & $\mathbf{x}$ & & & $\mathbf{x}$ & & & $\mathbf{x}$ & & & & & $\mathbf{x}$ \\
\hline L.C. & $\mathbf{x}$ & $\mathbf{x}$ & $\mathbf{x}$ & $\mathbf{x}$ & & $\mathbf{x}$ & $\mathbf{x}$ & $\mathbf{x}$ & & $\mathbf{x}$ & & \\
\hline R.W. & $\mathbf{x}$ & $\mathbf{x}$ & & $\mathbf{x}$ & & $\mathbf{x}$ & $\mathbf{x}$ & $\mathbf{x}$ & & $\mathbf{x}$ & & \\
\hline H.H. & $\mathbf{x}$ & $\mathbf{x}$ & & & & $\mathbf{x}$ & & $\mathbf{x}$ & & $\mathbf{x}$ & & \\
\hline$J \cdot \pi$ & $\mathbf{x}$ & & $\mathbf{x}$ & $\mathbf{x}$ & & $\mathbf{x}$ & $\mathbf{x}$ & $\mathbf{x}$ & & & & $\mathbf{x}$ \\
\hline $\mathrm{J}_{\dot{H}} \dot{H_{i}}$ & $\mathbf{x}$ & & & & $\mathbf{x}$ & & $\mathbf{x}$ & & $\mathbf{x}$ & $?$ & ? & ? \\
\hline $\mathrm{C}^{\mathrm{H}} \cdot \mathrm{M}$. & $\mathbf{x}$ & $\mathbf{x}$ & $\mathbf{x}$ & $\mathbf{x}$ & & $\mathbf{x}$ & $\mathbf{x}$ & $\mathbf{x}$ & & & & $\mathbf{x}$ \\
\hline
\end{tabular}

* $\mathrm{LE}=$ lupus erythematosus $; \mathrm{SLE}=$ systemic lupus erythematosus. 
TABLE II

Cryoprecipitation of $S L E$ sera. The effect of heating $\left(30\right.$ minutes at $\left.56^{\circ} \mathrm{C}\right)$ and reconstitution of precipitability by normal human serum reagents

\begin{tabular}{|c|c|c|c|c|c|c|c|c|c|c|c|}
\hline $\begin{array}{l}\text { Tube number: } \\
\text { Reagents mixed } \\
\text { Normal serur } \\
\text { SLE serum. } \\
1 \mathrm{ml}\end{array}$ & $\begin{array}{l}1 \\
\text { and incu } \\
1 \mathrm{ml} \\
\text { Un- } \\
\text { treated }\end{array}$ & $\begin{array}{l}\text { EDTA } \\
\mathbf{0 . 0 1} \mathbf{M}\end{array}$ & Heated & $\begin{array}{c}4 \\
\begin{array}{c}\text { Un- } \\
\text { treated }\end{array} \\
\text { Heated }\end{array}$ & $\begin{array}{l}\text { Heated } \\
\text { Heated }\end{array}$ & 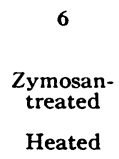 & $\begin{array}{c}7 \\
\underset{\text { Ammonia- }}{\text { treated }} \\
\text { Heated }\end{array}$ & $\begin{array}{c}8 \\
\text { Immune } \\
\text { ppt. } \\
\text { absorbed } \\
\text { Heated }\end{array}$ & $\begin{array}{c}9 \\
\begin{array}{c}\text { Eu- } \\
\text { globulin } \\
\text { (dialysis) }\end{array} \\
\text { Heated }\end{array}$ & $\begin{array}{c}10 \\
\begin{array}{c}\text { Super- } \\
\text { natant } \\
\text { fluid } \\
\text { (dialysis) }\end{array} \\
\text { Heated }\end{array}$ & 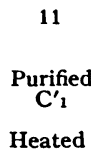 \\
\hline \multicolumn{12}{|c|}{ precipitate nitrogen, $\mu \mathrm{g} / \mathrm{ml}$ serum } \\
\hline $\begin{array}{l}\text { E.T. } \\
\text { C.H. } \\
\text { E.S. } \\
\text { H.M. } \\
\text { R.J. } \\
\text { J.C. } \\
\text { L.C. } \\
\text { R.W. } \\
\text { H.H. } \\
\text { J.R. }\end{array}$ & $\begin{array}{l}35 \\
12 \\
24 \\
30 \\
63 \\
27 \\
24 \\
24 \\
15 \\
20\end{array}$ & $\begin{array}{l}15 \\
28 \\
22 \\
28\end{array}$ & $\begin{array}{r}12 \\
2 \\
2 \\
18 \\
8 \\
5 \\
5 \\
6 \\
2 \\
2\end{array}$ & $\begin{array}{r}37 \\
18 \\
33 \\
33 \\
65 \\
30 \\
12 \\
22 \\
8 \\
15\end{array}$ & $\begin{array}{r}10 \\
2 \\
2 \\
17 \\
7 \\
7 \\
5 \\
7 \\
2 \\
2\end{array}$ & $\begin{array}{l}35 \\
15 \\
35 \\
25 \\
62 \\
32 \\
15 \\
22\end{array}$ & $\begin{array}{l}40 \\
13 \\
37 \\
23 \\
55 \\
32 \\
10 \\
17\end{array}$ & $\begin{array}{r}2 \\
2 \\
18 \\
8 \\
5 \\
5 \\
5 \\
2 \\
3\end{array}$ & $\begin{array}{l}12 \\
32 \\
37 \\
63 \\
22 \\
25 \\
22 \\
10 \\
15\end{array}$ & $\begin{array}{r}2 \\
0 \\
13 \\
5 \\
3 \\
5 \\
5 \\
2 \\
3\end{array}$ & $\begin{array}{l}45 \\
28 \\
24 \\
13 \\
18\end{array}$ \\
\hline $\begin{array}{l}\text { Mean ppt. } \\
\text { yield, } \%\end{array}$ & 100 & 112 & 23 & 100 & 23 & 101 & 95 & 21 & 100 & 16 & 116 \\
\hline
\end{tabular}

* For 48 hours at 0 to $4^{\circ} \mathrm{C}$.

$\dagger$ Relative to precipitate yield from untreated SLE sera.

(7) and quantitated as $50 \%$ hemolytic units. The following reagents were used: serum heated at $56^{\circ} \mathrm{C}$ for 30 minutes, serum absorbed with Zymosan ( $1.35 \mathrm{mg}$ per $\mathrm{ml}$ of serum), ammonia-treated serum, euglobulin precipitate, and supernatant fluid (dialysis method). Partially purified $\mathrm{C}^{\prime}{ }_{1}$ was prepared by the method of Lepow, Ratnoff, Rosen, and Pillemer (8). $11 \mathrm{~S}$ material was prepared from normal human sera as described by MüllerEberhard and Kunkel (9).

3. Cryoprecipitation was quantitated by placing measured samples of test sera into calibrated, 8-ml, conical centrifuge tubes. After refrigeration at 0 to $4^{\circ} \mathrm{C}$ for 48 hours, the tubes were centrifuged at $4^{\circ} \mathrm{C}$ and washed three times with cold isotonic saline. The washed precipitates were dissolved in 2 drops of $1 \mathrm{~N} \mathrm{NaOH}$ and diluted up to $3 \mathrm{ml}$ with water. Nitrogen contents of samples were estimated by the Folin-Ciocalteu reaction (10). The colorimetric method was standardized with a preparation of human $\boldsymbol{\gamma}$-globulin whose nitrogen content was determined by $\mathrm{Kjeldahl}$ analysis.

4. The characterization of a heat-labile component required for cryoprecipitation was obtained by adding normal serum reagents to SLE sera heated at $56^{\circ} \mathrm{C}$ for 30 minutes. With all reagents other than the $11 \mathrm{~S}$ material and purified $\mathrm{C}_{1}^{\prime}$, the equivalent of $1 \mathrm{ml}$ of treated normal serum was added to $1 \mathrm{ml}$ of heated SLE sera, and the incubation and quantitation were carried out as described above.

5. Sedimentation studies of dissolved cryoprecipitates $(0.15 \mathrm{M} \mathrm{NaCl}, 0.01 \mathrm{M}$ phosphate buffer at $\mathrm{pH} 7.4)$ were performed in a model $\mathrm{E}$ Spinco analytical ultracentrifuge.

6. The technique of Grabar and Williams was utilized in immunoelectrophoretic studies (11).

\section{RESULTS}

Table II presents data obtained from a study of 10 SLE sera demonstrating significant cryoprecipitation. The values for precipitate nitrogen ranged between 12 and $63 \mu \mathrm{g}$ nitrogen per $\mathrm{ml}$,

TABLE III

Effect of purified $C^{\prime}{ }_{1}$ in reconstituting cryoprecipitability of two heated* SLE sera

\begin{tabular}{|c|c|c|c|}
\hline $\begin{array}{c}\text { SLE sera } \\
\text { (1-ml samples) }\end{array}$ & \multicolumn{2}{|c|}{ Normal serum reagents added } & $\begin{array}{c}\text { Precipitate } \\
\text { nitrogen }\end{array}$ \\
\hline & & $m l$ & $\begin{array}{l}\mu g / m l \\
S L E \text { sera }\end{array}$ \\
\hline \multirow[t]{8}{*}{$\begin{array}{l}\text { J. C. Untreated } \\
\text { Heated* }^{*}\end{array}$} & & & $\begin{array}{r}27 \\
5\end{array}$ \\
\hline & Untreated serum: & 1 & 20 \\
\hline & Heated* serum : & & 4 \\
\hline & Purified $\mathrm{C}_{1}{ }^{\dagger}$ : & 0.1 & 4 \\
\hline & & 0.25 & 22 \\
\hline & & 0.5 & 41 \\
\hline & & 0.75 & 48 \\
\hline & & 1.0 & 48 \\
\hline \multirow{7}{*}{$\begin{array}{l}\text { R. J. Untreated } \\
\text { Heated }^{*}\end{array}$} & & & $\begin{array}{r}38 \\
5\end{array}$ \\
\hline & Untreated serum: & 1 & 39 \\
\hline & Heated* serum : & 1 & 4 \\
\hline & Purified $C_{1}^{\prime} \dagger$ : & 0.25 & 34 \\
\hline & & 0.75 & 32 \\
\hline & & 1.0 & $\begin{array}{r}32 \\
6\end{array}$ \\
\hline & & $0.25 t$ & 0 \\
\hline
\end{tabular}

* 30 minutes at $56^{\circ} \mathrm{C}$.

$+500 \mathrm{U} \mathrm{C}_{1}^{\prime}$ per ml.

$\ddagger$ Heated* after addition of purified $C^{\prime}{ }_{1}$. 
TABLE IV

Effect of $11 S$ material in reconstitution of cryoprecipitation of SLE sera

\begin{tabular}{|c|c|c|c|c|c|c|c|c|c|c|c|}
\hline $\begin{array}{l}\text { Tube number: } \\
\text { Reagents mixed } \\
\text { and incubated* } \\
\text { SLE serum, } 1 \mathrm{ml} \\
11 \mathrm{~S} \text { material, } \mu \mathrm{g} \\
\text { nitrogen added }\end{array}$ & $\begin{array}{c}1 \\
\text { Un- } \\
\text { treated }\end{array}$ & + & $\begin{array}{c}t \\
47\end{array}$ & $\begin{array}{l}t \\
14\end{array}$ & $\begin{array}{c}\dagger \\
14 \ddagger\end{array}$ & $\begin{array}{l}t \\
20\end{array}$ & $\begin{array}{c}\dagger \\
20 \ddagger\end{array}$ & $\begin{array}{l}t \\
50\end{array}$ & $\begin{array}{c}t \\
50 t\end{array}$ & $\begin{array}{c}t \\
100\end{array}$ & $\begin{array}{c}11 \\
+ \\
100 \ddagger\end{array}$ \\
\hline SLE sera & \multicolumn{11}{|c|}{ precipitate nitrogen, $\mu \mathrm{g} / \mathrm{ml}$ serum } \\
\hline $\begin{array}{l}\text { C.M. } \\
\text { E.T. } \\
\text { J.H. } \\
\text { J.R. }\end{array}$ & $\begin{array}{r}75 \\
44 \\
110 \\
20\end{array}$ & $\begin{array}{l}8 \\
4 \\
9 \\
5\end{array}$ & $\begin{array}{l}89 \\
88 \\
38\end{array}$ & 41 & 8 & 51 & 16 & 74 & 11 & 83 & 10 \\
\hline
\end{tabular}

* For 48 hours at 0 to $4^{\circ} \mathrm{C}$.

+ Heated 30 minutes at $56^{\circ} \mathrm{C}$.

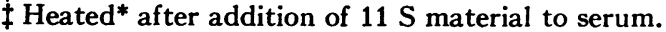

equivalent to 7 to $38 \mathrm{mg}$ per $100 \mathrm{ml}$. In all sera studied, heating at $56^{\circ} \mathrm{C}$ for 30 minutes significantly reduced cryoprecipitation, and the addition of untreated normal human serum to heatinactivated SLE sera partially or completely reconstituted cryoprecipitation. Zymosan-absorbed normal human serum (relatively deficient in $\mathrm{C}_{3}^{\prime}$ ), ammonia-treated serum (relatively deficient in $\mathrm{C}_{4}^{\prime}$ ), and the euglobulin fraction (relatively deficient in $\mathrm{C}_{2}^{\prime}, \mathrm{C}_{3}^{\prime}$, and $\mathrm{C}_{4}^{\prime}$ ) all reconstituted cryoprecipitation. Reagents lacking $\mathrm{C}^{\prime}{ }_{1}$ (heated normal human serum, immune precipitateabsorbed serum, and the supernatant fluid after removal of the euglobulin fraction) did not result in significant precipitation when added to heated SLE sera. Further evidence that $C^{\prime}{ }_{1}$ might be the heat-labile factor required for cryoprecipitation derived from the effect of purified $\mathrm{C}_{1}^{\prime}$ in reconstituting precipitation of heated SLE sera. More detailed studies of purified $C^{\prime}{ }_{1}$ in which graded amounts of this reagent were added to two heated SLE sera are summarized in Table III. Although purified $\mathrm{C}_{1}^{\prime}$ induced more precipitate than was obtained from untreated SLE serum in one subject (J.C.), a plateau effect was reached for both sera after addition of 0.25 to $0.5 \mathrm{ml}$ purified $\mathrm{C}_{1}{ }_{1}$; larger amounts did not result in significant increases in precipitate formation. When heated serum of Subject R.J. was reheated after addition of purified $\mathrm{C}_{1}^{\prime}$, the reconstituting property of the latter was lost.

Although the observations so far presented are compatible with the identification of the heat-labile component as $\mathrm{C}_{1}^{\prime}$, the finding that disodium ethyl-

TABLE V

Reconstitution of cryoprecipitation of a heated SLE serum by the addition of varying amounts of $11 S$ material

\begin{tabular}{|c|c|c|c|c|c|c|c|c|c|c|c|c|c|}
\hline Tube number: & 1 & 2 & 3 & 4 & 5 & 6 & 7 & 8 & 9 & 10 & 11 & 12 & 13 \\
\hline \multicolumn{14}{|l|}{ Normal serum (M.F.), ml } \\
\hline $\begin{array}{l}\text { Untreated } \\
\text { Heated* }\end{array}$ & 1 & 1 & 1 & & & & & & & & & & \\
\hline \multicolumn{14}{|l|}{ SLE serum (E.T.), ml } \\
\hline $\begin{array}{l}\text { Untreated } \\
\text { Heated* } \\
\text { Supernatant fluid } \dagger\end{array}$ & & & & 1 & 1 & 1 & 1 & 1 & 1 & 1 & 1 & 1 & 1 \\
\hline \multicolumn{14}{|l|}{$11 \mathrm{~S}$ material } \\
\hline $\begin{array}{l}\text { Nitrogen added, } \mu \mathrm{g} \\
\text { Nitrogen added, } \neq \mu \mathrm{g}\end{array}$ & & & 45 & & & 9 & 18 & 45 & 90 & 180 & 45 & & 45 \\
\hline Precipitate nitrogen, $\mu \mathrm{g}$ per $\mathrm{ml}$ & 3 & 3 & 4 & 44 & 9 & 8 & 67 & 125 & 126 & 116 & 12 & 4 & 52 \\
\hline
\end{tabular}

* Thirty minutes at $56^{\circ} \mathrm{C}$

$\dagger$ After removal of cryoprecipitate from untreated serum.

$\ddagger$ Heated $^{*}$ after addition of $11 \mathrm{~S}$ material to serum. 


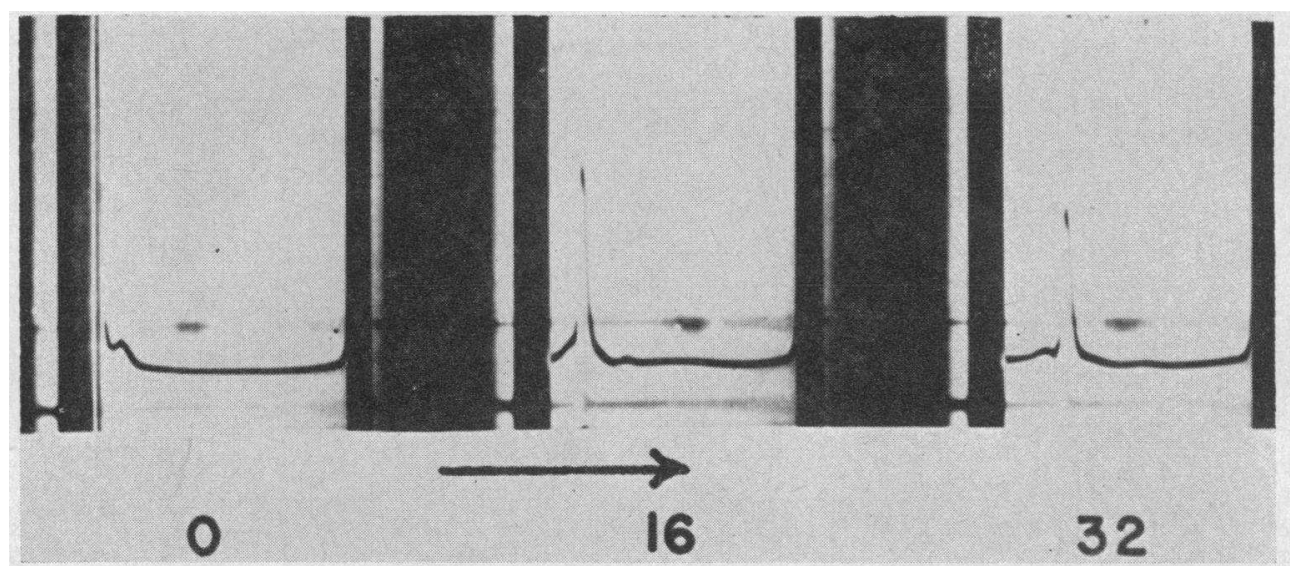

Fig. 1. Analytical Ultracentrifuge pattern of $11 \mathrm{~S}$ material. Sedimentation was at $47,660 \mathrm{rpm}$ in direction of arrow; exposure intervals, in minutes, are indicated. Small quantities of components with S constants of approximately 19 and 7 are present.

enediaminetetraacetic acid (EDTA) failed to prevent cryoprecipitation is evidence to the contrary. [All evidence indicates that calcium is required for the interaction of $\mathrm{C}_{1}^{\prime}$ with immune complexes (12-14).] In 3 of the 4 SLE sera studied with EDTA, the chelating agent resulted in increased cryoprecipitation over that observed with untreated sera. A newly characterized component of hemolytically active complement (11 S component) has properties in common with the
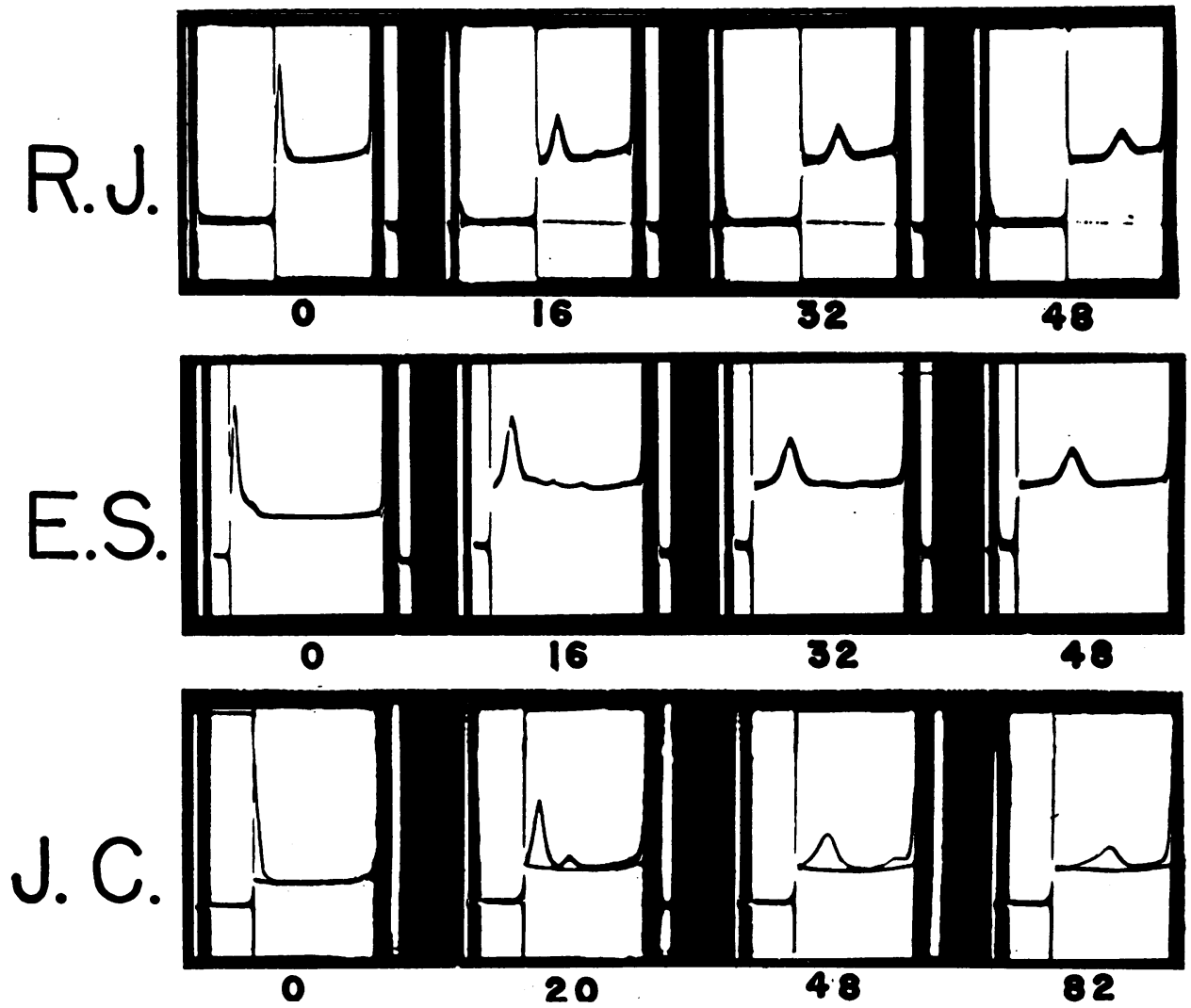

Fig. 2. Analytical ultracentrifuge patterns of 3 purified cryoproteins. Sedimentation was at 46,660 rpm. Exposure intervals, in minutes, are indicated. The major component in each sample has an S-constant of 6 to 7. More rapidly sedimenting components are also seen. 


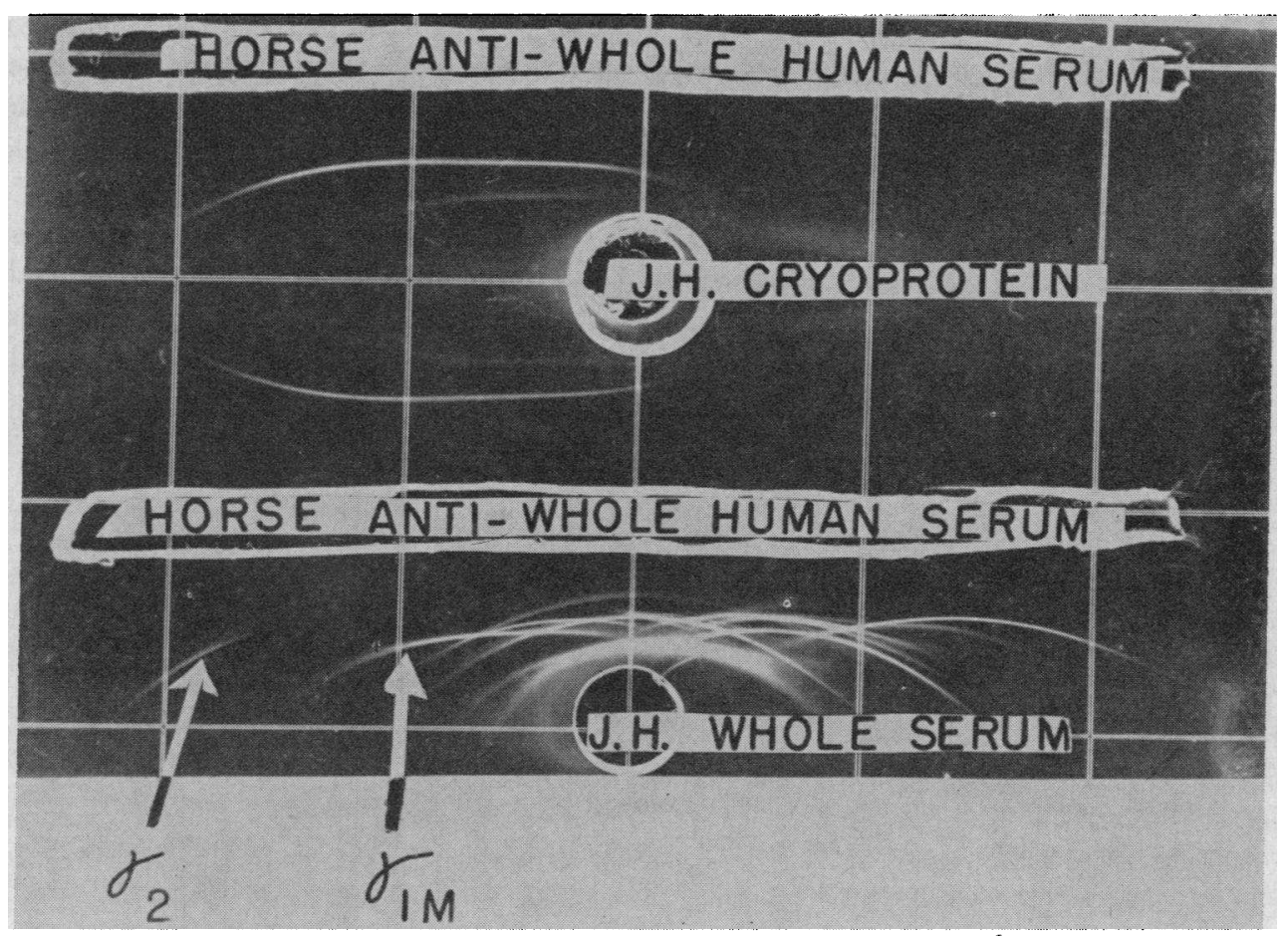

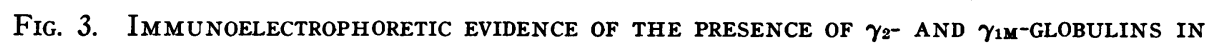
PURIFIED SLE CRYOPROTEIN.

normal serum factor required for reconstitution of cryoprecipitation of heated SLE sera: 1) heat lability, 2) coexistence with $\mathrm{C}_{1}^{\prime}$ in standard complement reagents, and 3 ) normal or increased effect in the presence of EDTA $(9,15)$.

Table IV summarizes studies in which small amounts of $11 \mathrm{~S}$ material reconstituted cryoprecipitation of 4 heated SLE sera (Figure 1 illustrates a sedimentation pattern of the $11 \mathrm{~S}$ material used). When 2 sera (C.M. and E.T.) were reheated after addition of the $11 \mathrm{~S}$ material, increased precipitation did not occur. Other studies with $11 \mathrm{~S}$ material are presented in Table $\mathrm{V}$. Amounts of $11 \mathrm{~S}$ material varying between 9 and $180 \mu \mathrm{g}$ nitrogen were added to samples of a heated SLE serum. A plateau effect was reached with $45 \mu \mathrm{g}$ nitrogen; a further, fourfold increase in $11 \mathrm{~S}$ material did not increase cryoprecipitation. Forty-five $\mu \mathrm{g} 11 \mathrm{~S}$ material did not induce precipitation when added to normal human serum. When $11 \mathrm{~S}$ material was added to the supernatant fluid of untreated SLE serum after removal of cryoprecipitate, further precipitation was induced, indicating that for this serum, the $11 \mathrm{~S}$ material was the limiting reactant required for cryoprecipitation.
Analytical ultracentrifuge studies were performed on purified cryoproteins obtained from 8 SLE sera. In most cases, a small residue of precipitate was not soluble on warming to $37^{\circ} \mathrm{C}$, so that materials in solution may not have reflected the total composition of cryoproteins. Sedimentation patterns of 3 cryoproteins are illustrated in Figure 2. All of the cryoproteins examined demonstrated predominantly $7 \mathrm{~S}$ material with varying quantities of more rapidly sedimenting components.

Purified cryoproteins from 4 SLE sera were studied by immunoelectrophoresis with horse antihuman antiserum. Two antigens, $\gamma_{2^{-}}$and $\gamma_{1 M^{-}}$-globulins, were consistently demonstrable (see Figure 3).

\section{DISCUSSION}

Occasional reference has been made to the association of SLE and cryoproteinemia. Coburn and Moore, in an electrophoretic study of certain SLE sera, noted a dense precipitation in the part of the Tiselius tube containing globulin (16). Barr, Reader, and Wheeler found significant cryoproteinemia in 8 of 121 random human sera (17). Three of these 8 were SLE sera (total of 6 SLE 
sera included in the 121 studied). Waldenström referred to a single case of SLE that exhibited cryoproteinemia (18).

The magnitude of cryoprecipitation reported here $(7$ to $38 \mathrm{mg}$ per $100 \mathrm{ml}$ ) is equivalent to grade 2 cryoglobulinemia in Lerner's studies. Cryoproteinemia of this degree is rarely encountered. Our group of patients is not a random sampling of SLE patients. Screening tests were applied to virtually all hospitalized patients, although the outpatient population was incompletely surveyed. All patients with cryoproteinemia, however, showed signs of active SLE. During the 3 years of study, 18 of 33 sera examined contained at least $10 \mu \mathrm{g}$ nitrogen per $\mathrm{ml}$ serum. Of these patients, 8 are known to have died; significant renal disease was present in 15 ; only 5 patients had Raynaud's symptoms.

The requirement of a component of complement (11 S material) for cryoprecipitation may be significantly related to the nature of the reactants participating in precipitate formation and to the pathogenesis of SLE. Heat-labile cryoprecipitation in another report concerned a patient with "essential cryoglobulinemia" (19).

Current knowledge suggests that the $11 \mathrm{~S}$ component of complement reacts with immune complexes or with aggregates of $\gamma$-globulin. $[\gamma-$ Globulin aggregates share other properties with immune complexes: reactivity with rheumatoid factor $(20,21)$ and the capacity to induce cutaneous inflammatory lesions $(22,23)$.] The precipitation of otherwise soluble components of SLE sera by $11 \mathrm{~S}$ material is apparently analogous to the action of complement in rendering soluble immune complexes insoluble (24-26). The presumed aggregates in SLE sera that are reactive with $11 \mathrm{~S}$ material might be either the products of nonspecific aggregation of $\gamma$-globulin, or, conceivably, immune complexes. The evidence of this report does not clearly support one of the above possibilities to the exclusion of the other. The $\gamma$-globulin constituents of dissolved cryoproteins could represent antibodies dissociated from immune complexes, but the antigen of the hypothetical immune complex was not demonstrable. One could postulate that the immune complexes might be anti- $\gamma$-globulin antibodies in combination with autologous $\gamma$-globulin. Such a basis has been suggested for the intermediate complexes of $\gamma$ globulin observed in certain rheumatoid sera (27).

Evidence of in vivo fixation of complement in SLE derives from demonstrations of low total serum complement (28-30). A study of components of complement revealed depressions of the $11 \mathrm{~S}$ material as well as decreases in other components in SLE sera (31). Immunoelectrophoretic studies of SLE sera demonstrated marked reduction of a globulin, $\mathrm{B}_{1 \mathrm{c}}$-globulin, subsequently shown to be a component of complement $(32,33)$. Immunofluorescent studies demonstrated the presence of $B_{1 c}$-globulin in renal lesions of SLE (34). In another immunofluorescent study, complement (defined as human serum components complexing with immune complexes) was demonstrated in renal lesions of SLE (35).

Our observations are compatible with the thesis that either antigen-antibody complexes or nonimmune aggregates of $\gamma$-globulin exist in the sera of SLE patients. Tissue injury by such complexes, perhaps with the mediation of serum complement, could account for the varied pathologic features of SLE.

\section{SUM MARY}

Selected sera of systemic lupus erythematosus (SLE) demonstrated cryoprecipitation that was dependent on a heat-labile serum factor. The heat-labile component was present in normal human sera and was identified as a component of complement (11 S material). These observations, in addition to previous studies of complement in SLE, are consistent with the thesis that immune complexes exist in SLE sera.

\section{REFERENCES}

1. Mackay, I. R., N. Eriksen, A. G. Motulsky, and W. Volwiler. Cryo- and macroglobulinemia. Electrophoretic, ultracentrifugal and clinical studies. Amer. J. Med. 1956, 20, 564.

2. Lerner, A. B., and C. J. Watson. Studies of cryoglobulins. I. Unusual purpura associated with the presence of a high concentration of cryoglobulin (cold precipitable serum globulin). Amer. J. med. Sci. 1947, 214, 410.

3. Lerner, A. B., C. P. Barnum, and C. J. Watson. Studies of cryoglobulins. II. The spontaneous precipitation of protein from serum at $5^{\circ} \mathrm{C}$ in various disease states. Amer. J. med. Sci. 1947, 214, 416.

4. Christian, C. L. A study of rheumatoid arthritis sera: comparison of spontaneous precipitates and 
gamma globulin-induced precipitates. Arthr. and Rheum. 1959, 2, 289.

5. Epstein, W. V., E. P. Engleman, and M. Ross. Quantitative studies of the precipitation and agglutination reactions between serum of patients with "connective tissue" diseases and a preparation (Cohn fraction II) of human gamma globulin. J. Immunol. 1957, 79, 441.

6. LoSpalluto, J., B. Dorward, W. Miller, Jr., and M. Ziff. Cryoglobulinemia based on interaction between a gamma macroglobulin and $7 \mathrm{~S}$ gamma globulin. Amer. J. Med. 1962, 32, 142.

7. Kabat, E. A., and M. M. Mayer. Experimental Immunochemistry. Springfield, Ill., Charles C Thomas, 1948, p. 117.

8. Lepow, I. H., O. D. Ratnoff, F. S. Rosen, and L. Pillemer. Observations on pro-esterase associated with partially purified first component of human complement $\left(\mathrm{C}_{1}^{\prime}\right)$. Proc. Soc. exp. Biol. (N. Y.) 1956, 92, 32.

9. Müller-Eberhard, H. J., and H. G. Kunkel. Isolation of a thermolabile serum protein which precipitates $\gamma$-globulin aggregates and participates in immune hemolysis. Proc. Soc. exp. Biol. (N. Y.) 1961, 106, 291.

10. Heidelberger, M., and C. F. C. MacPherson. Quantitative micro-estimation of antibodies in sera of man and other animals. Science 1943, 97, 405 (and 98,63).

11. Grabar, P., and C. A. Williams. Méthode permettant l'étude conjugée des propriétés électrophorétiques et immunochimiques d'un mélange de protéines. Application au sérum sanguin. Biochim. biophys. Acta (Amst.) 1953, 10, 193.

12. Levine, L., K. M. Cowan, A. G. Osler, and M. M. Mayer. Studies on role of $\mathrm{Ca}^{++}$and $\mathrm{Mg}^{++}$in complement fixation and immune hemolysis. $\mathrm{J}$. Immunol. 1953, 71, 359.

13. Maurer, P. H., and W. Weigle. Persistence of complement in aged sera. J. Immunol. 1953, 71, 284.

14. Kabat, E. A. Experimental Immunochemistry. Springfield, Ill., Charles C Thomas, 1948.

15. Taranta, A., H. S. Weiss, and E. C. Franklin. Precipitating factor for aggregated $\gamma$-globulins in normal human sera. Nature (Lond.) 1961, 189, 239.

16. Coburn, A. F., and D. H. Moore. The plasma proteins in disseminated lupus erythematosus. Bull. Johns Hopk. Hosp. 1943, 73, 196.

17. Barr, D. P., G. G. Reader, and C. H. Wheeler. Cryoglobulinemia. I. Report of 2 cases with discussion of clinical manifestations, incidence and significance. Ann. intern. Med. 1950, 32, 6.

18. Waldenström, J. Pathological globulins and protein synthesis. Exp. Med. Surg. 1954, 12, 187.

19. Volpé, R., A. Bruce-Robertson, A. A. Fletcher, and W. B. Charles. Essential cryoglobulinaemia. Review of the literature and report of a case treated with ACTH and cortisone. Amer. J. Med. 1956, 20, 533.
20. Christian, C. L. Studies of aggregated $\gamma$-globulin. I. Sedimentation, electrophoretic and anticomplementary properties. J. Immunol. 1960, 84, 112.

21. Edelman, G. M., H. G. Kunkel, and E. C. Franklin. Interaction of the rheumatoid factor with antigenantibody complexes and aggregated gamma globulin. J. exp. Med. 1958, 108, 105.

22. Ishizaka, T., and K. Ishizaka. Biological activities of aggregated gamma globulin. I. Skin reactive and complement-fixing properties of heat denatured gamma globulin. Proc. Soc. exp. Biol. (N. Y.) 1959, 101, 845.

23. Christian, C. L. Studies of aggregated $\boldsymbol{\gamma}$-globulin. II. Effect in vivo. J. Immunol. 1960, 84, 117.

24. Maurer, P. H., and D. W. Talmage. The effect of the presence of complement in rabbit serum on the quantitative precipitin reaction. II. Effect of antigen and antibody precipitation. J. Immunol. 1953, 70, 435.

25. Weigle, W. O., and P. H. Maurer. The effect of complements on soluble antigen-antibody complexes. J. Immunol. 1957, 79, 211.

26. Weigle, W. O., and P. H. Maurer. The effect of chemical and physical treatments of sera on the hemolytic activities and fixation of complement nitrogen by antigen-antibody precipitates. J. Immunol. 1957, 79, 370.

27. Kunkel, H. G., H. J. Müller-Eberhard, H. H. Fudenberg, and T. B. Tomasi. Gamma globulin complexes in rheumatoid arthritis and certain other conditions. J. clin. Invest. 1961, 40, 117.

28. Vaughan, J. H., T. B. Bayles, and C. B. Favour. Response of serum gamma globulin level and complement titer to adrenocorticotropic hormone $(\mathrm{ACTH})$ therapy in lupus erythematosus disseminatus. J. Lab. clin. Med. 1951, 37, 698.

29. Elliott, J. A., Jr., and D. R. Mathieson. Complement in disseminated (systemic) lupus erythematosus. Arch. Derm. Syph. (Berl.) 1953, 68, 119.

30. Williams, R. C., Jr., and D. H. Law IV. Serum complement in connective tissue disorders. J. Lab. clin. Med. 1958, 52, 273.

31. Morse, J. H., H. J. Müller-Eberhard, and H. G. Kunkel. Antinuclear factors and serum complement in systemic lupus erythematosus. Bull. N. Y. Acad. Med. 1962, 38, 641.

32. Seligmann, M., and C. Hanau. Etude immunoélectrophorétique du sérum de malades atteints de lupus érythémateux disséminé. Rev. Hémat. 1958, 13, 239.

33. Müller-Eberhard, H. J., and U. Nilsson. Relation of a $\boldsymbol{\beta}_{1}$-glycoprotein of human serum to the complement system. J. exp. Med. 1960, 111, 217.

34. Lachmann, P. J., H. J. Müller-Eberhard, H. G. Kunkel, and F. Paronetto. The localization of in vivo bound complement in tissue sections. $\mathrm{J}$. exp. Med. 1962, 115, 63.

35. Freedman, P., and A. S. Markowitz. Gamma globulin and complement in the diseased kidney. J. clin. Invest. 1962, 41, 328. 